\title{
EKONOMICZNE KONSEKWENCJE ZMNIEJSZAJĄCEJ SIE LICZBY STUDENTÓW W OŚRODKACH AKADEMICKICH W POLSCE
}

\begin{abstract}
Zarys treści: Zmniejszająca się liczba studentów w Polsce wpływa z jednej strony na funkcjonowanie całego systemu szkolnictwa wyższego oraz na sytuację poszczególnych szkół wyższych, z drugiej strony natomiast generuje szereg konsekwencji ekonomicznych dla miast akademickich. W opracowaniu na podstawie danych statystycznych GUS zaprezentowano zmiany w liczebności osób studiujących w wojewódzkich miastach akademickich w okresie 2006-2015 oraz podjęto próbę określenia charakteru ekonomicznych konsekwencji wynikających z ubytku liczby studentów w ośrodkach kształcenia na poziomie wyższym.
\end{abstract}

Słowa kluczowe: Studenci, zmiany demograficzne, miasta akademickie.

\section{Wprowadzenie}

Jednymi z najważniejszych czynników determinujących tzw. „,boom edukacyjny”, przejawiający się we wzroście liczby osób podejmujących studia było, po pierwsze wkraczanie roczników wyżu demograficznego w wiek umożliwiający studiowanie (Antonowicz, Gorlewski 2011), a po drugie wzrost aspiracji edukacyjnych polskiego społeczeństwa, na zaspokajanie których pozwoliły zmiany systemowe dotyczące szkolnictwa wyższego w Polsce (Inglot-Brzęk 2012). Skutkiem tego był ponad pięciokrotny wzrost liczby studentów w Polsce - z poziomu 390 tys. na początku lat 90. XX wieku (Szkolnictwo wyższe w Polsce 2013) do prawie $2 \mathrm{mln}$ w 2006 roku (Bank Danych Lokalnych) - roku rekordowego pod względem liczby osób studiujących. Jednak w kolejnych latach sukcesywnie dochodziło do spadku liczby osób studiujących - w 2015 roku liczba studentów w kraju wyniosła już 1,4 mln osób (Bank Danych Lokalnych) ${ }^{1}$.

${ }^{1}$ Szerzej o przyczynach zmniejszającej się liczby studentów w: D. Rokita-Poskart (2017). 
Wracając jednak do początków procesu umasowienia się studiów wyższych w Polsce należy zauważyć, że wzrost liczby osób studiujących generował szereg konsekwencji w skali makro, przejawiając się m.in. wzrostem udziału osób posiadających wykształcenie wyższe w całej populacji oraz wzrostem współczynnika skolaryzacji w poszczególnych grupach wiekowych (Górniak red. 2015), ale generował także szereg konsekwencji o charakterze mikro, determinując funkcjonowanie poszczególnych szkół wyższych (Inglot-Brzęk 2012). Masowy napływ studentów do ośrodków akademickich niósł za sobą również cały wachlarz skutków w skali lokalnej - przede wszystkim ich wpływ na funkcjonowanie poszczególnych miast: na przekształcenia przestrzeni miejskiej (Chatterton 1999; Allinson 2006; Markowski, Drzazga red. 2008; Wolaniuk 2008; Haase, Grossmann, Steinführer 2012; Murzyn-Kupisz, Szmytkowska 2012), na przekształcenia rynku mieszkaniowego (Rugg, Rhodes, Jones 2000, 2002; Ogur 2011; Grabowska 2012; Krakowski rynek nieruchomości 2015; Murzyn-Kupisz, Szmytkowska 2015) oraz zmiany struktury podmiotów gospodarczych zlokalizowanych w lokalnej przestrzeni (Dembicka 2010; Kotus, Rzeszewski, Bajerski 2015; Murzyn-Kupisz, Szmytkowska 2015). Rosnąca liczba studiujących $\mathrm{w}$ miastach generowała także zmiany typowo ekonomiczne - poprzez wzrost liczby konsumentów studenci pobudzali lokalny popyt konsumpcyjny (Steinacker 2005; Marcinowicz, Kaczmarek, Gaczek 2006; Rokita-Poskart 2016a), poprzez fakt podejmowania pracy powiększali lokalne zasoby pracy i nade wszystko determinowali funkcjonowanie lokalnych przedsiębiorstw (Munro, Turok, Livingston 2009; Beblavý, Fabo 2015). Jednak w obliczu obserwowanych obecnie zmian demograficznych przejawiających się m.in. spadkiem liczby osób w wieku ,akademickim” oraz spadkiem liczby studiujących, miasta akademickie w Polsce stają przez nowymi, nieznanymi dotąd wyzwaniami.

Celem niniejszego artykułu jest ukazanie zarówno zmian liczby studentów w wojewódzkich miastach akademickich w Polsce, jak i zasygnalizowanie będących następstwem tego procesu skutków w wymiarze mezoekonomicznym. W zaprezentowanej analizie, oprócz wykorzystania danych Głównego Urzędu Statystycznego dotyczących liczby studentów w polskich miastach wojewódzkich, wykorzystano również dane dotyczące liczby podmiotów gospodarczych funkcjonujących w tych miastach. W opracowaniu posiłkowano się także wynikami badań empirycznych prowadzonych w jednym z takich miast w Polsce - w Opolu.

Struktura niniejszego artykułu jest następująca. W pierwszej kolejności, wykorzystując dane statystyczne, ukazano zmiany absolutne oraz relatywne liczby osób studiujących w miastach akademickich w dziesięcioletnim okresie obejmującym lata 2006-2015. W dalszej kolejności przedstawiono analizę mechanizmu powstawania „strat” w lokalnej gospodarce wynikających z ubytku studentów, 
koncentrując się przy tym na zmianach na lokalnym rynku towarowo-usługowym oraz rynku pracy miast akademickich. Zaprezentowano również wyniki analizy korelacji pomiędzy liczbą studentów a liczbą podmiotów gospodarczych w wybranych ośrodkach. Zaprezentowany w opracowaniu materiał analizowano przez pryzmat najważniejszych z punktu widzenia tematyki niniejszego opracowania teorii rozwoju lokalnego i regionalnego.

\section{Zmiany liczby studentów w wojewódzkich miastach akademickich w latach 2006-2015}

W świetle przedstawionych we wstępie rozważań dotyczących uwarunkowań społeczno-demograficznych obserwowanych przemian w szkolnictwie wyższym, warto przyjrzeć się nieco bliżej zmianom liczebności osób studiujących w wybranych do analizy miastach akademickich. Dane dotyczące tego zagadnienia zaprezentowano w tabeli 1.

$\mathrm{Z}$ danych zaprezentowanych $\mathrm{w}$ tabeli 1 wynika, że w samej Warszawie w $2006 \mathrm{r}$. studiowało ok. 280 tys. studentów. Z kolei w czterech innych jeszcze miastach liczba studentów przekraczała wówczas 100 tys. - były nimi Kraków, Wrocław, Poznań oraz Łódź. Z kolei miastami liczącymi najmniej studentów były dwa ośrodki zlokalizowane w województwie lubuskim - Gorzów Wielkopolski (ok. 11,2 tys. studentów) oraz Zielona Góra (19,3 tys. studentów). Jednak niezależnie od wielkości ośrodka akademickiego, w niemal każdym z nich w okresie 10 lat doszło to spadku liczby studentów. Co ciekawe, największy bezwzględny spadek liczby studentów nie nastąpił w mieście, które w okresie wyjściowym charakteryzowało się największą liczbą studentów, czyli w Warszawie (spadek o 36,2 tys. osób), lecz w Łodzi, gdzie liczba studentów w analizowanym okresie zmniejszyła się aż o 39,5 tys. Innymi miastami, które charakteryzowały się dużym spadkiem liczby osób studiujących były położone międzymetropolitalnie Kielce (spadek o 24,6 tys. osób) oraz położony peryferyjnie Szczecin (spadek o 24,4 tys. osób). Jak można było przypuszczać, najmniejsze bezwzględne spadki studentów odnotowano w Rzeszowie oraz w miastach liczących w okresie wyjściowym relatywnie niewielu studentów - w Zielonej Górze, Gorzowie Wielkopolskim,

\footnotetext{
${ }^{2}$ Uwzględnienie do analizy wyłącznie ośrodków wojewódzkich - wynikało z dostępności danych statystycznych. I tak biorąc pod uwagę ograniczoną dostępność danych zdecydowano się na prezentację liczby studentów podejmujących studia w Trójmieście, a nie w Gdańsku oraz pominięto, ze względu na brak dostępu do danych, liczbę studentów dla Gorzowa Wielkopolskiego oraz Zielonej Góry w 2007 roku. Z kolei wyjaśniając dziesięcioletni horyzont czasowy obejmujący lata 2006-2015 kierowano się chęcią porównania liczby studentów w roku kulminacyjnym pod względem tej liczby dla całego szkolnictwa wyższego w Polsce z najnowszymi dostępnymi danymi dla analizowanego zagadnienia.
} 


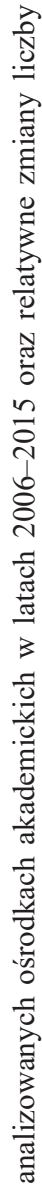

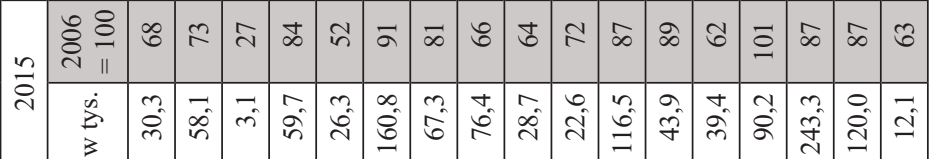

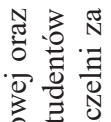

施

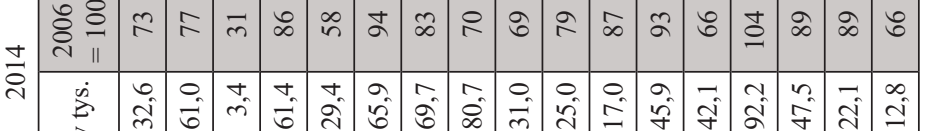
至

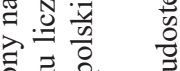

m 눙 웅

개

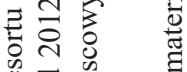

㝏

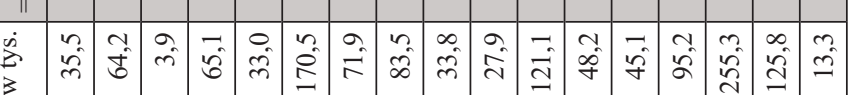
$0 \%$

$\sqrt{5}$

ठํ ஓ

귱

究

- ¿̊ํㅇ

롱

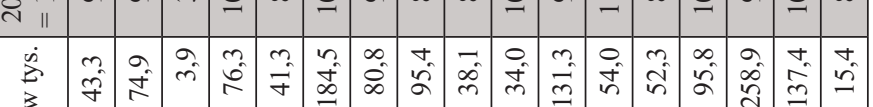

월

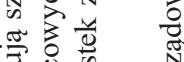

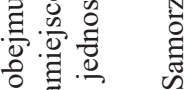

38

:

\& \& $\delta$ ठ

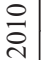

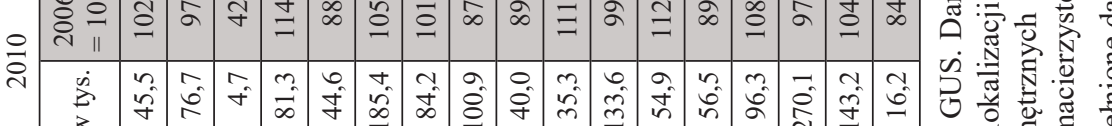

墕

可

$\overline{8}$ क

苞

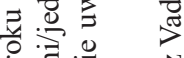

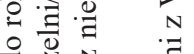

氜

0 夰

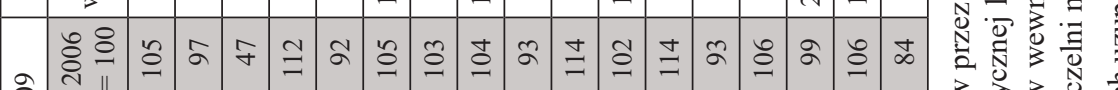

ڤे

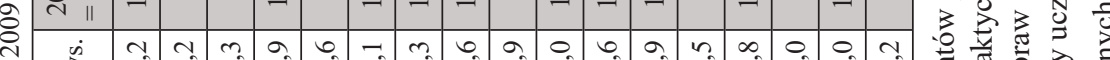

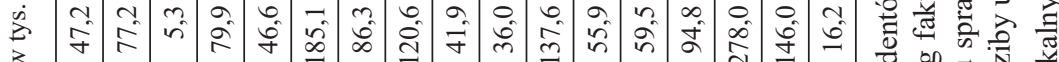

\section{ஓ̊ำ}

$\stackrel{\infty}{8}$ 些焉 क 0 $\because 30 \overline{0}$

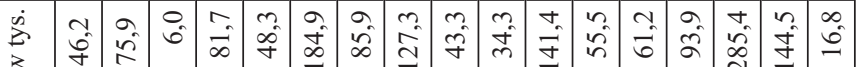

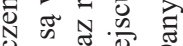

\section{हิ) \\ ‡̊ ̊ำ

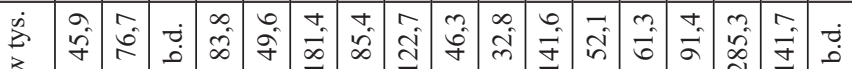

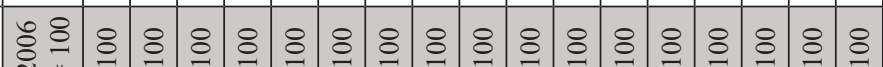

3 ग

营

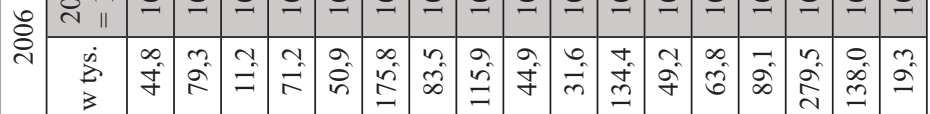

瓷

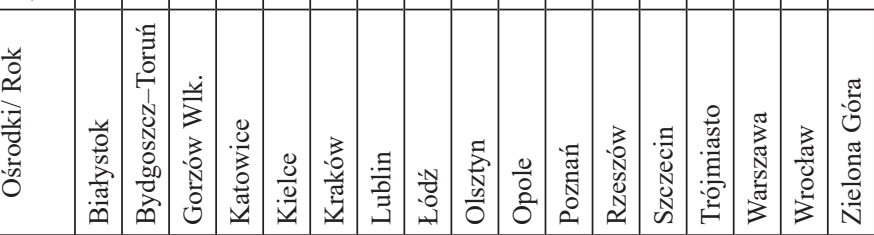

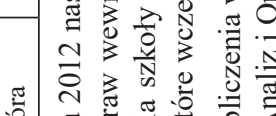
$:=$ 舫 का

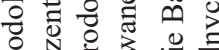

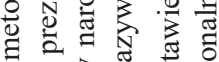

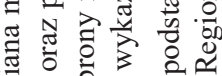

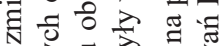
त 娄

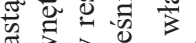

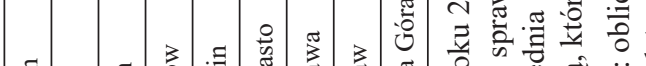

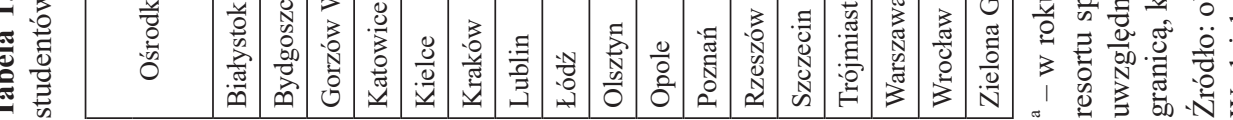


Opolu. Z kolei najkorzystniejsza sytuacja pod względem zmian bezwzględnej liczby studentów w analizowanym okresie wystąpiła w Trójmieście - liczba studentów w analizowanym okresie wzrosła o prawie 2 tys. osób ${ }^{3}$.

Szczegółowa analiza relatywnych zmian liczby studentów w miastach akademickich w Polsce rzuca nowe światło na rozważane zagadnienie. Analiza ta wskazuje, że miastem w którym odnotowano największy procentowy spadek liczby studiujących jest Gorzów Wielkopolski - liczba studiujących w nim osób w dziesięcioletnim okresie zmniejszyła się dramatycznie, bo o ponad $70 \%$. Innym miastem wyróżniającym się relatywnie dużym procentowym spadkiem liczby studiujących były także Kielce, gdzie liczba studentów zmniejszyła się o około $50 \%$. W jeszcze innej grupie miast, do której po analizie relatywnej zmiany liczby studentów zakwalifikowano - Szczecin, Zieloną Górę, Olsztyn, Łódź, Białystok oraz Opole i Bydgoszcz-Toruń - wspomniane spadki oscylowały wokół 30-35\%. Najmniejszym procentowym spadkiem liczby studentów - nieprzekraczającym $20 \%$ - charakteryzowały się takie miasta, jak: Lublin, Katowice, Poznań, Wrocław, Warszawa, Rzeszów oraz Kraków.

Analizowane zmiany thumaczyć można przez pryzmat niektórych teorii rozwoju lokalnego i regionalnego - w tym miejscu zwłaszcza w kontekście teorii biegunów wzrostu (Grzeszczak 1999). Zgodnie z jej założeniami relatywnie niewielki spadek liczby studentów w silnych centrach metropolitalnych w Polsce - takich, jak Warszawa, Kraków, Wrocław czy Poznań analizować należy przez pryzmat lokalizacji biegunów wzrostu dla całego otoczenia społeczno-gospodarczego, a przede wszystkim dla całego szkolnictwa wyższego w Polsce. Miasta te nie dość, że są postrzegane jako „centra decyzji i kontroli” (Purchla 2011), w których dochodzi do polaryzacji ,jednostek napędowych" (Piętak 2014), to jeszcze zlokalizowane są w nich prestiżowe uczelnie, które przyciągają do miast studentów z całego kraju. W obliczu coraz mniej licznych roczników wkraczających w wiek uprawniający do studiowania, w silnych ośrodkach akademickich obserwuje się relatywnie najmniejszy spadek studiujących, bowiem przyciągają one także młodzież z innych regionów Polski. W tym przypadku część młodych osób rezygnuje ze studiowania $w$ mniejszych ośrodkach na rzecz większych i silniejszych, nie tylko ze względu na prestiż uczelni, ale również, a może przede wszystkim, z uwagi na korzystniejszą sytuację na lokalnym rynku pracy metropolii (Jończy, Rokita-Poskart, Tanas 2013).

${ }^{3} \mathrm{~W}$ Trójmieście, podobnie jak w kilku innych miastach, rokiem rekordowym pod względem liczby osób studiujących był rok 2012. Od tego momentu odnotowano w Trójmieście ubytek liczby studiujących o 8,5 tys. osób. 


\section{Wybrane ekonomiczne ,straty" w miastach akademickich wynikające z mniejszej liczby studentów}

Spadek liczby studentów obserwowany w niemal wszystkich analizowanych miastach akademickich niesie za sobą szereg istotnych konsekwencji. W tym miejscu zasygnalizowano jedynie te, które zachodzą na lokalnym rynku towarowo-usługowym oraz rynku pracy. Sekwencja następujących po sobie zmian porównana do mechanizmu „błędnego koła” została zaprezentowana na ryc. 1 .

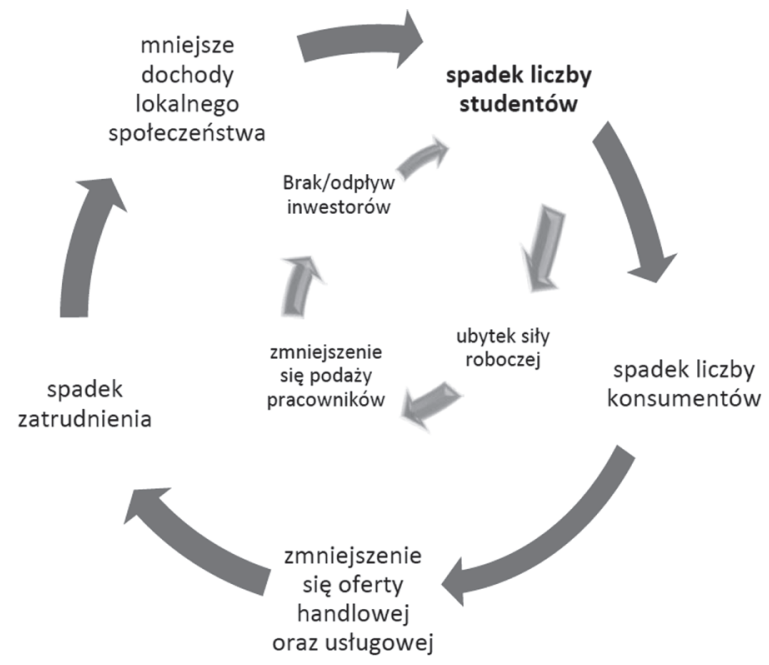

Ryc. 1. Mechanizm błędnego koła związany z ubytkiem liczby studentów

Źródło: opracowanie własne na podstawie prowadzonych badań oraz T. Stryjakiewicz (2014: 14).

Ubytek liczby studentów traktować można jako impuls generujący kolejno następujący po sobie szereg konsekwencji. Z jednej strony spadek liczby studentów dotyka lokalnego rynku towarowo-usługowego - prowadzić może do mniejszej liczby konsumentów, co z kolei w dłuższej perspektywie oznaczać może pogorszenie się wyników finansowych przedsiębiorstw zaspokajających popyt studentów oraz zmniejszenie się oferty handlowej oraz usługowej w miastach. W następstwie wspomnianego procesu można obserwować spadek zatrudnienia oraz dochodów wśród lokalnego społeczeństwa.

Z drugiej strony ubytek studiujących może generować szereg konsekwencji dla lokalnego rynku pracy miast akademickich. Jak pokazują badania prowadzone w Opolu ${ }^{4}$, znaczna część studentów w trakcie nauki podejmuje pracę w miejscu

${ }^{4}$ Badania na temat wpływu studentów na sytuację gospodarczą opolskiego ośrodka akademickiego prowadzono Opolu w latach 2013-2015. Pokłosiem tych badań są m.in. publikacje D. Rokita-Poskart (2016a, 2016b). 
podejmowania studiów, zatem ubytek studentów prowadzi w nich do strat siły roboczej oraz spadku podaży pracy. W następstwie tego ograniczony zostaje dostęp do specyficznej grupy niewykwalifikowanych jeszcze pracowników, deklarujących chęć pracy w elastycznych godzinach oraz posiadających niewygórowane oczekiwania finansowe. W dłuższej perspektywie, spadek liczby studiujących ograniczać może również dostęp do wykwalifikowanych absolwentów studiów wyższych oraz hamować możliwości miast w zakresie przyciągania oraz absorpcji inwestorów, prowadząc w konsekwencji do kształtowania się negatywnych trendów na lokalnym rynku pracy (Malecki 1985; Rees, Stafford 1986; Dziemianowicz 1997; Stryjakiewicz 2009; Szymańska, Płaziak 2014; Wierzbicka 2015). Wspomniane zmiany, zarówno na rynku towarowym oraz rynku pracy, mogą ograniczać możliwości przyciągania studentów przez ośrodki akademickie. Można przypuszczać, że opisane zdarzenia kumulują się zwłaszcza w tych miastach, w których odnotowano znaczne procentowe ubytki w liczbie studiujących. Sytuację tą dość dobrze można wytłumaczyć przez pryzmat teorii skumulowanej przyczynowości. W miastach tych daje się obserwować swoisty mechanizm „błędnego koła” przytaczany przez twórcę wspomnianej koncepcji - w związku z tym, że rozwój koncentruje się w silnych centrach (Grosse 2002), to mniejsze i jednocześnie słabsze ośrodki akademickie, m.in. takie, jak wspomniany już Gorzów Wielkopolski oraz Kielce, w których i tak dochodzi już do negatywnych procesów demograficzno-ekonomicznych, nie stanowią istotnego magnesu przyciągającego studentów. W tych miastach dochodzi do kumulowania się negatywnych zmian, w konsekwencji czego pogrążają się one w jeszcze większej stagnacji zarówno w sensie ekonomicznym, jak i demograficznym.

Aby potwierdzić przypuszczenia o wpływie ubytku liczby studentów z niektórymi symptomami kryzysu lokalnej gospodarki, można posłużyć się analizą korelacji pomiędzy liczbą studentów a liczbą przedsiębiorstw. Do analizy tej wykorzystano dane statystyczne dotyczące liczby studiujących w wybranych miastach $(x)$ oraz dane dotyczące liczby przedsiębiorstw w zakwalifikowanych do dwóch wybranych sekcji Polskiej Klasyfikacji Działalności (PKD) - y. Zdecydowano się na wybór przedsiębiorstw z dwóch sekcji, które zgodnie z wynikami wspominanych już w niniejszym opracowaniu badań są beneficjentami wydatków napływających do ośrodka studentów oraz, w których to podmiotach studenci podejmują pracę w trakcie studiów (Rokita-Poskart 2016a, 2016b). Zdecydowano się zatem na wybór przedsiębiorstw zakwalifikowanych do sekcji G działu 47 - handel detaliczny, z wyłączaniem handlu detalicznego pojazdami samochodowymi oraz sekcji I działu 56, do którego zakwalifikowano działalność usługową związaną z wyżywieniem. W związku z dostępnością danych, analizę korelacji przeprowadzono dla wybranych zmiennych w latach 2009-2015. W analizie tej wykorzystano wzór na korelację liniową Pearsona: 


$$
\frac{\operatorname{cov}(x, y)}{\sigma_{x} \times \sigma_{y}}
$$

gdzie:

$x$ - liczba studentów,

$y$ - liczba przedsiębiorstw zakwalifikowanych do sekcji G dział 47 oraz sekcji

I dział 56 według PKD,

$\operatorname{cov}(x, y)$ - kowariancja pomiędzy $x$ i $y$,

$\sigma$ - odchylenie standardowe w populacji.

Wyniki tej analizy zaprezentowano w tabeli 2.

Tabela 2. Wartości współczynnika korelacji Pearsona dla zmiennych $x$ i $y$ w wybranych ośrodkach akademickich

\begin{tabular}{|c|c|}
\hline $\begin{array}{l}\text { Wojewódzkie ośrodki } \\
\text { akademickie }\end{array}$ & $\begin{array}{l}\text { Współczynnik korelacji } \\
\text { cech } x \text { i } y\end{array}$ \\
\hline Białystok & $-0,60554$ \\
\hline Bydgoszcz-Toruń & 0,96578 \\
\hline Gorzów Wielkopolski & 0,882047 \\
\hline Katowice & 0,889911 \\
\hline Kielce & 0,973133 \\
\hline Kraków & $-0,10845$ \\
\hline Lublin & 0,777578 \\
\hline Łódź & 0,212321 \\
\hline Olsztyn & 0,906112 \\
\hline Opole & 0,947723 \\
\hline Poznań & $-0,89058$ \\
\hline Rzeszów & $-0,75126$ \\
\hline Szczecin & 0,959318 \\
\hline Trójmiasto & 0,155307 \\
\hline Warszawa & $-0,79065$ \\
\hline Wrocław & 0,174082 \\
\hline Zielona Góra & $-0,76614$ \\
\hline
\end{tabular}

Źródło: opracowanie własne na podstawie Banku Danych Lokalnych GUS. 
Analiza współczynnika korelacji Pearsona dowiodła, że w zasadzie w miastach, które odnotowały największe procentowe spadki liczby studentów wystąpiła silna korelacja pomiędzy wybranymi zmiennymi - liczbą studentów a liczbą podmiotów zakwalifikowanych do obu wybranych do analizy sekcji PKD. W tym miejscu szczególną uwagę zwrócić należy na takie miasta, jak Gorzów Wielkopolski, Kielce, Szczecin, Olsztyn oraz Opole, które w analizowanym okresie doświadczyły spadku liczby studentów przekraczający 30\% i dla których współczynnik korelacji Pearsona dla obu zmiennych wyniósł odpowiednio 0,88 , $0,97,0,95,0,90$ oraz 0,94 . Otrzymane wyniki analizy korelacji mogą świadczyć o zależności pomiędzy mniejszą liczbą studentów a mniejszą liczbą lokalnych przedsiębiorstw zaspokajających popyt studentów.

Prezentowane „straty”, będące następstwem zmian w liczbie osób studiujących, można analizować przez pryzmat jednej z najbardziej popularnych koncepcji rozwoju regionalnego - teorii bazy ekonomicznej. Według niej podstawowym źródłem rozwoju regionalnego jest działalność egzogeniczna, a jej podstawowym elementem pobudzającym procesy rozwoju staje się popyt zewnętrzny na produkty i usługi wytwarzane lokalnie i regionalnie (Grosse 2002). Napływających do miast akademickich studentów należałoby w tym przypadku traktować jako podmioty zewnętrzne, które zgłaszają popyt na produkty i usługi oferowane przez podmioty lokalnej gospodarki. W tym przypadku dokonuje się „sprzedaż” produktów i usług - przyjezdni studenci konsumują produkcję lokalną - zarówno usługi edukacyjne, jak i produkty i usługi oferowane na lokalnym rynku. Popyt ten inicjować może szeroko pojęte procesy rozwoju zarówno w sferze przedsiębiorczości, wpływając na większe zatrudnienie, dochody oraz wielkość produkcji. Tym samym w sytuacji obserwowanej obecnie zmniejszającej się liczby studentów w większości miast akademickich, zwłaszcza tych, które bazowały głównie na swej akademickości, regres ten może stanowić zagrożenie dla funkcjonowania wielu podmiotów gospodarczych oraz może prowadzić do ich likwidacji.

\section{Zakończenie}

W niniejszym artykule zasygnalizowano najważniejsze, w opinii autorki, ekonomiczne konsekwencje zmniejszającej się liczby studentów dla wojewódzkich miast akademickich w Polsce. Zaprezentowane zmiany dotyczą przede wszystkim rynku towarowo-usługowego, rynku pracy oraz funkcjonowania lokalnych przedsiębiorstw. W przypadku tych ostatnich, zmniejszająca się liczba studentów oznacza spadek przychodów, czasem tak duży, że zagrażający istnieniu niektórych podmiotów gospodarczych. Innymi, zasygnalizowanymi w niniejszym opracowaniu ekonomicznymi konsekwencjami spadku liczby studentów jest mniejsza podaż pracy potęgowana dodatkowo przez deficyty lokalnych zasobów pracy, 
zwłaszcza w mniejszych, peryferyjnych ośrodkach, do których dochodzi na skutek procesów wewnętrznego bądź zewnętrznego odpływu ludności. Jeszcze inną konsekwencją ubytku studentów dla lokalnych rynków pracy miast akademickich może być zmniejszenie się popytu na pracę wśród lokalnych przedsiębiorstw - skoro bowiem dochodzi do spadku popytu na towary i usługi generującego spadek przychodów przedsiębiorstw, podważa to także sens funkcjonowania wielu miejsc pracy w lokalnej gospodarce miast akademickich.

Nie bez znaczenia jest również to, że wskazane w artykule konsekwencje nie dotyczą wyłącznie analizowanych - wojewódzkich ośrodków akademickich, ale dotyczą wszystkich bez wyjątku miast, w których zlokalizowane są szkoły wyższe. Są one jednak dużo bardziej dotkliwe, jak pokazuje przeprowadzona w niniejszym artykule analiza dla ośrodków peryferyjnych, których dotychczasowy rozwój w znacznej mierze opierał się na funkcji akademickiej. W przypadku takich miast, ,strategie rozwoju [...] były dotychczas w zbyt małym stopniu skorelowane z potencjałem strategicznym uczelni wyższych, działających na ich terenie" (Domański 2011) i wydaje się, że dopiero w momencie drastycznego ubytku studentów zaczęły one dostrzegać ich niepodważalną rolę w kreowaniu dalszego rozwoju lokalnego.

Na zakończenie należy jeszcze dodać, że wskazane konsekwencje stanowią jedynie wycinek zmian, do których może dojść w miastach w wyniku zmniejszającej się liczby studentów. Bez wątpienia, co warto podkreślić, zmniejszanie się ich liczby w ośrodkach nie należy postrzegać jedynie pejoratywnie. Ubytek ten może prowadzić do wielu pozytywnych zmian, takich jak zmniejszenie się liczby konfliktów studentów z dotychczasowymi mieszkańcami miast, ograniczeniem niekontrolowanego rozprzestrzeniania się studentów w ośrodkach akademickich (Smith 2002; Sage, Smith, Hubbard 2012; Bajerski 2015) czy też spadku cen na lokalnym rynku nieruchomości z korzyścią dla uczestników strony popytowej tego rynku.

\section{Literatura}

Allinson J., 2006, Over-educated, over-exuberant and over here? The impact of students on cities, „Planning, Practice and Research”, 1: 79-94.

Anderson J., 2013, Studentification, Cardiff Case Studies.

Antonowicz D., Gorlewski B., 2011, Demograficzne tsunami. Raport Instytutu Sokratesa na temat wptywu zmian demograficznych na szkolnictwo wyższe do 2020 roku, Instytut Rozwoju Kapitału Intelektualnego im. Sokratesa. Warszawa.

Bajerski A., 2015, Student jako użytkownik miasta: brytyjskie doświadczenia studentyfikacji, „Rozwój Regionalny i Polityka Regionalna”, 31: 47-56.

Bank Danych Lokalnych, https://bdl.stat.gov.pl/BDL/dane/podgrup/tablica.

Beblavý M., Fabo B., 2015, Students in Work and their Impact of the Labour Market, „CEPS Working Document”, 410: 1-31. 
Chatterton P., 1999, University students and city centres - the formation of exclusive geographies. The case of Bristol, UK, „Geoforum”, 2: 117-133.

Dembicka A., 2010, Funkcja akademicka jako czynnik wpływajacy na rozwój usług $w$ mieście Opolu, [w:] Sitek S. (red.), Stare i nowe problemy badawcze $w$ geografii społeczno-ekonomicznej, Polskie Towarzystwo Geograficzne, Sosnowiec: 215-221.

Domański T., 2011, Rola uniwersytetów w promocji polskich miast i regionów - nowe wyzwania strategiczne, [w:] Domański T. (red.), Marketing akademicki. Rola uniwersytetów w promocji miast i regionów, Wydawnictwo Uniwersytetu Łódzkiego, Łódź: 15-32.

Dziemianowicz W., 1997, Kapitał zagraniczny a rozwój regionalny i lokalny $w$ Polsce, „Studia Regionalne i Lokalne”, 21(54).

Górniak J. (red.), 2015, Prognoza rozwoju szkolnictwa wyższego do 2020 r., Część III: Diagnoza szkolnictwa wyższego, Warszawa: 1-119.

Grabowska M., 2012, Regeneration of the Post-Socialist Inner City. Social Change and Bottom-up Transformation in Gdańsk, Gdańsk: 1-35.

Grosse T.G., 2002, Przeglad koncepcji teoretycznych rozwoju regionalnego, „Studia Regionalne i Lokalne", 1(8): 25-48.

Grzeszczak J., 1999, Bieguny wzrostu a forma przestrzeni spolaryzowanej, „Prace Geograficzne", 173, Instytut Geografii i Przestrzennego Zagospodarowania PAN.

Haase A., Grossmann K. Steinführer A., 2012, Transitory urbanites: New actors of residential change in Polish and Czech inner cities, „Cities”, 29: 318-326.

Inglot-Brzęk E., 2012, Przemiany demograficzne a rozwój szkolnictwa wyższego w Polsce, „Nierówności Społeczne a Wzrost Gospodarczy”, 26: 216-229.

Jończy R., Rokita-Poskart D., Tanas M., 2013, Eksodus absolwentów szkół średnich województwa opolskiego do dużych ośrodków regionalnych kraju oraz za granice, Wojewódzki Urząd Pracy w Opolu, Uniwersytet Ekonomiczny we Wrocławiu, Opole-Wrocław.

Kotus J., Rzeszewski M., Bajerski A., 2015, Przyjezdni w strukturach miasta - miasto wobec przyjezdnych: studenci i turyści $w$ mieście $w$ kontekście koncepcji city users, Bogucki Wydawnictwo Naukowe, Poznań.

Krakowski rynek nieruchomości 2014, 2015, Urząd Miasta Krakowa, Kraków.

Malecki E., 1985, Industrial Location and Corporate Organization in High Technology Industries, „Economic Geography”, 61: 345-369.

Marcinowicz D., Kaczmarek M., Gaczek W., 2006, Poznański Ośrodek Akademicki. Próba określenia wptywu studentów na rozwój miasta, Bogucki Wydawnictwo Naukowe, Poznań: 162-170.

Markowski T., Drzazga D. (red.), 2008, Rola wyższych uczelni w rozwoju społeczno-gospodarczym i przestrzennym miast, KPZK PAN, Warszawa: 162-170.

Munro M., Turok I., Livingston M., 2009, Students in cities: a preliminary analysis of their patterns and effects, „Environment and Planning”, A 41(8): 1805-1825.

Murzyn-Kupisz M., Szmytkowska, M., 2012, Procesy studentyfikacji w przestrzeni polskich miast: na przykładzie Krakowa i Trójmiasta, [w:] Jakóbczyk-Gryszkiewicz J. (red.), XXV Konwersatorium Wiedzy o Mieście, Wydawnictwo Uniwersytetu Łódzkiego, Łódź: 199-219.

Murzyn-Kupisz M., Szmytkowska M., 2015, Studentification in the postsocialist context: The case of Cracow and the Tri-City (Gdansk, Gdynia and Sopot), „Geografie”, 120(2): 188-209. 
Ogur J.D., 2011, The Impact of Colleges and Universities on Local Rental Housing Markets, „American Journal of Economics and Sociology”, 32: 387-394.

Piętak Ł., 2014, Teoria biegunów wzrostu F. Perrouix i implementacja jej założén w Hiszpanii w latach 1964-1975, „Ekonomia XXI wieku”, 1(1): 185-205.

Purchla J., 2011, Miasto i uniwersytet wobec wyzwań współczesności, Tekst wykładu inauguracyjnego wygłoszonego na Uniwersytecie Ekonomicznym w Krakowie 3 października 2011 roku.

Rees J., Stafford H., 1986, Theories of Regional Growth and Industrial Location: Their Relevance for Understanding High-Technology Complex, [w:] Rees J. (red.), Technology, Regions and Policy, Washington: 24-50.

Rokita-Poskart D., 2016a, Educational migration and the labour market, „Czech Journal of Social Sciences, Business and Economics", 5(1): 6-17.

Rokita-Poskart D., 2016b, Studiować i pracować? Aktywność zawodowa studentów opolskiego ośrodka akademickiego (na podstawie wyników badań empirycznych), [w:] Zagórowska A. (red.), Edukacja młodzieży a rynek pracy, Uniwersytet Opolski, WUP w Opolu, Opole: 128-137.

Rokita-Poskart D., 2017, Wojewódzkie miasta akademickie wobec zmian demograficznych w Polsce, ,Przegląd Nauk Stosowanych”, 12: 66-76.

Rugg J., Rhodes D., Jones A., 2000, The Nature and Impact of Student Demand on Housing Markets, Joseph Rowntree Foundation, York.

Rugg J., Rhodes D., Jones A., 2002, Studying a niche market: UK students and the private rented sector, „Housing Study”, 17(2): 289-303.

Sage J., Smith D., Hubbard P., 2012, The diverse geographies of studentification: living alongside people not like us, „Housing Studies”, 27(8): 1057-1078.

Smith D.P., 2002, Patterns and processes of studentification in Leeds, „Regional Review”, 12(1): 14-16.

Steinacker A., 2005, The Economic Effect of Urban Colleges on their Surrounding Communities, „Urban Studies”, 42(7): 1161-1175.

Stryjakiewicz T., 2009, Lokalizacja firm i zachowania przestrzenne pracowników sektora informatycznego (na przykładzie poznańskiego obszaru metropolitalnego), Prace Komisji Geografii Przemysłu Polskiego Towarzystwa Geograficznego, 13.

Stryjakiewicz T. (red.), 2014, Kurczenie się miast $w$ Europie Środkowo-Wschodniej, Bogucki Wydawnictwo Naukowe, Poznań: 14.

Szkolnictwo wyższe w Polsce, 2013, Ministerstwo Nauki i Szkolnictwa Wyższego, Warszawa.

Szymańska I., Płaziak M., 2014, Klasyczne czynniki w procesie lokalizacji przedsiębiorstwa na wybranych przykładach, „Przedsiębiorczość-Edukacja”, 10: 71-84.

Wierzbicka W., 2015, Czynniki lokalizacji przedsiębiorstw $w$ warunkach zmienności otoczenia, ,Zeszyty Naukowe Uniwersytetu Przyrodniczo-Humanistycznego w Siedlcach", 106: 239-250.

Wolaniuk A., 2008, Rola i miejsce wyższych uczelni wyższych $w$ organizacji przestrzeni miast, [w:] Markowski T., Drzazga D. (red.), Rola wyższych uczelni w rozwoju spoteczno-gospodarczym i przestrzennym miast, Studia KPZK PAN, Warszawa. 


\title{
ECONOMIC CONSEQUENCES OF "THE SHRINKING" NUMBER OF STUDENTS IN ACADEMIC CITIES IN POLAND
}

\begin{abstract}
The decline of students number in Poland affects, on the one hand, the whole higher education system and the situation of individual higher education institutions, but on the other hand, generates a number of economic consequences for academic cities. The study, based on GUS statistical data, presents changes in the number of students in the voivodeships capitals in the period 2006-2015. In the paper attempts were made to determine the economic nature of the consequences resulting from the loss of the number of students in Polish academic cities.
\end{abstract}

Keywords: Students, demographic changes, academic cities.

Dr Diana Rokita-Poskart Katedra Polityki Regionalnej Wydział Ekonomii i Zarządzania Politechnika Opolska e-mail: d.rokita@po.opole.pl 